\title{
Horn growth pattern in Cantabrian chamois Rupicapra pyrenaica parva: Influence of sex, location and phaenology
}

\author{
Francisco J. PÉREZ-BARBERÍA, Luis ROBLES and Carlos NORES
}

Pérez-Barbería F. J., Robles L. and Nores C. 1996. Horn growth pattern in Cantabrian chamois Rupicapra pyrenaica parva: Influence of sex, location and phaenology. Acta Theriologica 41: 83-92.

Sexual dimorphism in Cantabrian chamois Rupicapra pyrenaica parva (Cabrera, 1911) horn length was recorded annually for the first five years of life. The horns of males were larger than those of females, though horn growth rate in the first two years (ie horn length in the first two years divided by horn length in the first five years) was greater in females than males. Sexual dimorphism in horn length of Cantabrian chamois adults was found to be the highest of genus according to available data. Males and females with faster horn growth in the first two years of life reduced their horn growth rate in the third and fourth year. Chamois' horns from the Eastern Cantabrian Mountains were smaller than those from Western Cantabrian Mountains, although at five years of age these differences were not evident. Total horn length and jaw length showed significant positive correlation (females: $r_{\mathrm{P}}{ }^{2}=0.75$, males: $r_{\mathrm{P}}{ }^{2}$ $=0.54, p<0.05$ in both cases). This relationship suggests that horn growth dynamics may be used as an estimation of body-size dynamics. Horn growth / jaw length correlation was higher in females than in males. Horn growth was also positively correlated with annual precipitation in the previous year, but not with precipitation in the current year. Winter horn growth was observed in the younger age classes. Post-winter horn growth was recorded in 55\% of the animals in March. The use of this information to age Cantabrian chamois is described.

Facultad de Biología, Dpto. Biología de Organismos y Sistemas, Universidad de Oviedo, 33071-Oviedo, Spain (FJP-B, CN); C/ El Pinar 1, Villaobispo de las Regueras, 22195-Leon, Spain (LR)

Key words: Rupicapra pyrenaica parva, horn growth dynamics, Cantabrian Mountains, Spain

\section{Introduction}

Chamois of both sexes are characterized by hook-like horns derived from epidermal tissue. Horn growth is a continuous process throughout an animals life, although the growth rate can be affected by season, the rut in males, pregnancy, lactation in females, and disease (Niethammer 1957). These factors produce marks along the horn. Often, narrow boundaries represent winter marks, caused by a cessation of horn growth, as Couturier (1938) suggested, or a reduced rate of growth in that season (Schröder 1971, Koubek and Hrabě 1983a). Wide segments between two boundaries correspond to a fast horn growth rate. Throughout an 
animals life, the horn growth rate diminishes and annual growth is constant after five years of age (Koubek and Hrabě 1983a).

Although the systematics of Rupicapra is still unclear (Nascetti et al. 1985, Miller and Hartl 1986, Masini and Lovari 1988), ten subspecies have been described, each from different mountain chains (Schröder 1985). Information about skull and horn morphometrics is available for most subspecies: Rupicapra rupicapra rupicapra (Couturier 1938, Hrabě and Koubek 1983, Koubek and Hrabě 1983a), R. r. cartusiana (Couturier 1938), R. r. tatrica (Hrabě and Koubek 1984, Koubek and Hrabě 1984), R. r. carpatica (Couturier 1938, Koubek et al. 1985, Hrabě et al. 1986), R. r. asiatica (Couturier 1938, Lovari and Scala 1984), R. $r$. caucasica (Couturier 1938, Koubek and Hrabě 1983b), R. r. balcanica (Couturier 1938, Massei et al. 1994), R. r. pyrenaica, R. p. ornata (Couturier 1938, Scala and Lovari 1984, Fernández-López and García-González 1986). For $R$. p. parva only Couturier's scant (1938) data and the study by Fernández-López and García-González (1986) are available, and these studies do not deal with horn growth dynamics.

The aim of this study is to analyse the pattern of horn growth and identify sexual and regional differences in the Cantabrian chamois. Relationships between horn size and jaw length, and the influence of annual rainfall on horn growth are described.

\section{Study area and methods}

The available material (142 females, 198 males and 6 unknown sex animals of Cantabrian chamois, Rupicapra pyrenaica parva) came from private hunting trophies, collections and animals shot between 1964 and 1994, a large percentage of which were collected in order to monitor the incidence of sarcoptic mange (131 individuals in 1994 in Asturias). Casualities due to natural causes provided some additional data. The samples were collected from throughout the whole area of distribution of this subspecies in the Cantabrian Mountains from Cantabria to western Asturias, including animals from the León region. Two study areas were established, Area 1: Eastern Cantabrian Mountains (Picos de Europa and Covadonga National Park), Area 2: Western Cantabrian Mountains (Aller, Caso, Riaño and Mampodre regions). The following data were recorded: length of each growth segment along frontal edge $\pm 0.1 \mathrm{~mm}$ of the left horn (right horn was used when the left was broken or worn); total horn length $\pm 1 \mathrm{~mm}$ (hereafter THL); jaw length $\pm 0.1 \mathrm{~mm}$ (from processus angularis to the exterior edge alveolus of $\mathrm{I}_{4}$ tooth; age; date of death, and the starting date of post-winter horn growth. Individuals found dead were sexed using discriminant analysis with animals of known sex. The boundary between the 1st and 2nd annual growth increment is unclear in Cantabrian chamois. The growth increments of the first two years were therefore pooled (Koubek and Hrabě 1983a, Massei et al. 1994). Jaw length can be measured with accuracy and it has been used extensively as an indicator of body size in other ungulate species (Mitchell and Crisp 1981, Reimers 1983, Skogland 1989). Horn measurements were made by two different researchers, although differences due to this factor were not detected $\left(F_{70,1}=0.972, p=0.328\right)$. Age was estimated using annual horn growth increments (Couturier 1938, Pflieger 1982, Bargagli and Lovari 1984, Schröder and Elsner-Schack 1985, Pérez-Barbería and Fernández-López, in press), taking the 1st of May as the putative birth date (Pérez-Barbería 1994a). From birth to 12 months of age, an animal was considered to be within the one-year old age class, and one year was added every birthday. 
The terminology used for each horn annual growth increment is as follows: $\mathrm{L}_{1+2}$ - increment of the first two years, $\mathrm{L}_{3}$ - increment of the third year, $\mathrm{L}_{4}$ - increment of the fourth year; and L5 increment of the fifth year. As horn growth continues throughout a chamois' life, the length of the first five segments (from now on, $\mathrm{L}_{1+5}$ ) was taken as a reference length, against which the length of each increment was scaled (Koubek and Hrabě 1983a and Massei et al. 1994 consider the first 6 years). $R L_{1+2}$ is the relative length of $L_{1+2}$ with respect to $L_{1+5}\left(R L_{1+2}=L_{1+2} / L_{1+5}\right), R L_{3}$ is the same for $\mathrm{L}_{3}\left(R \mathrm{R}_{3}=\mathrm{L}_{3} / \mathrm{L}_{1+5}\right.$ ), and so on. Although $R \mathrm{~L}_{n}$ is a measurement which includes two non-independent lengths (because $\mathrm{L}_{1+5}$ includes the other horn segments), the comparisons of $\mathrm{RL}_{\mathrm{n}}$ between areas and sexes are valid because there was no variation due to these factors. In order to assess the formation date of the horn boundaries, individuals older than 2 years were used, because the boundaries from the first two years were unmarked.

Relationships between horn growth and rainfall were analyzed using $\mathrm{L}_{3}$ and $\mathrm{L}_{4}$. Although $\mathrm{L}_{1+2}$ showed the highest annual horn growth increment, $\mathrm{L}_{1+2}$ was not used as it contains the pooled increments of two different years. From these annual increments an annual horn growth index (GI) was calculated (Bunnell 1978). A set of nine years were selected, each containing at least 5 individuals. As Bunnell's index (1978) compared the annual increment of a given year with the mean of all years, the years which have a large number of individuals bias the value of the mean. In order to avoid this, the index was modified by replacing the arithmetic mean by a weighted mean.

\section{Results}

\section{Horn growth pattern: differences between areas and sexes}

$\mathrm{L}_{1+5}$ did not differ between areas $\left(F_{1,164}=0.767, p=0.382\right)$, but it differed between sexes $\left(F_{1,164}=367.32, p<0.001\right)$. Interaction between area and sex was not significant.

$\mathrm{L}_{1+2}$ showed sexual dimorphism, with larger horns in males than in females. This trend recurred in each annual increment (Table 1). In Area 2, $\mathrm{L}_{1+2}$ is larger than in Area 1, but this trend was reversed for $\mathrm{L}_{3}$ (Table 1). $\mathrm{L}_{4}$ and $\mathrm{L}_{5}$ did not show significant differences between areas (Table 1).

$\mathrm{RL}_{1+2}$ was larger in Area 2 than in Area 1, but the trend was reversed for $\mathrm{RL}_{3}$ and $\mathrm{RL}_{4}$ (Table 2). $\mathrm{RL}_{5}$ did not show differences between areas. $\mathrm{RL}_{1+2}$ was significantly larger in females than in males. The opposite was the case with RL4. In $R_{3}$ and $R L_{5}$, differences between sexes were not detected (Table 2). The percentages of each annual increment in relation to $\mathrm{L}_{1+5}$ varied for females between $\mathrm{L}_{1+2}: 71-75 \%, \mathrm{~L}_{3}: 31-41 \%, \mathrm{~L}_{4}: 7 \%, \mathrm{~L}_{5}: 3 \%$ and for males between $\mathrm{L}_{1+2}$ : 68-74\%, L3: 44-49\%, L4: 11-13\%, L5: 4\%.

Animals, which showed fast horn growth throughout the first two years of life, had reduced growth during the third and fourth year. This was observed in both areas and for both sexes, except for $\mathrm{L}_{4}$ and $\mathrm{L}_{3}$ in females from Area 2 (correlation coefficients, $\mathrm{L}_{3}$ versus $\mathrm{L}_{1}+2$, Area 1: females, $r_{\mathrm{P}}=-0.50$; males, $r_{\mathrm{P}}=-0.59$; Area 2: males, $r_{\mathrm{P}}=-0.49$; L4 versus $\mathrm{L}_{1+2}$, Area 1: females, $r_{\mathrm{P}}=-0.40$; males, $r_{\mathrm{P}}=-0.39$; Area 2: males, $r_{\mathrm{P}}=-0.26 ; p<0.05$ in all cases). Considering $\mathrm{L}_{1+2}$ versus $\mathrm{L}_{3}$, the regression lines for females between areas did not differ in elevation and slope (ANCOVA; $F_{1,78}=2.10, p<0.05 ; F_{1,77}=1.06, p<0.05$; respectively. Snedecor and Cochran 1975). The regression lines for males differed in elevation between areas $\left(F_{1,121}=9.35, p<0.01\right)$, but they did not differ in slope (Fig. 1 ). 


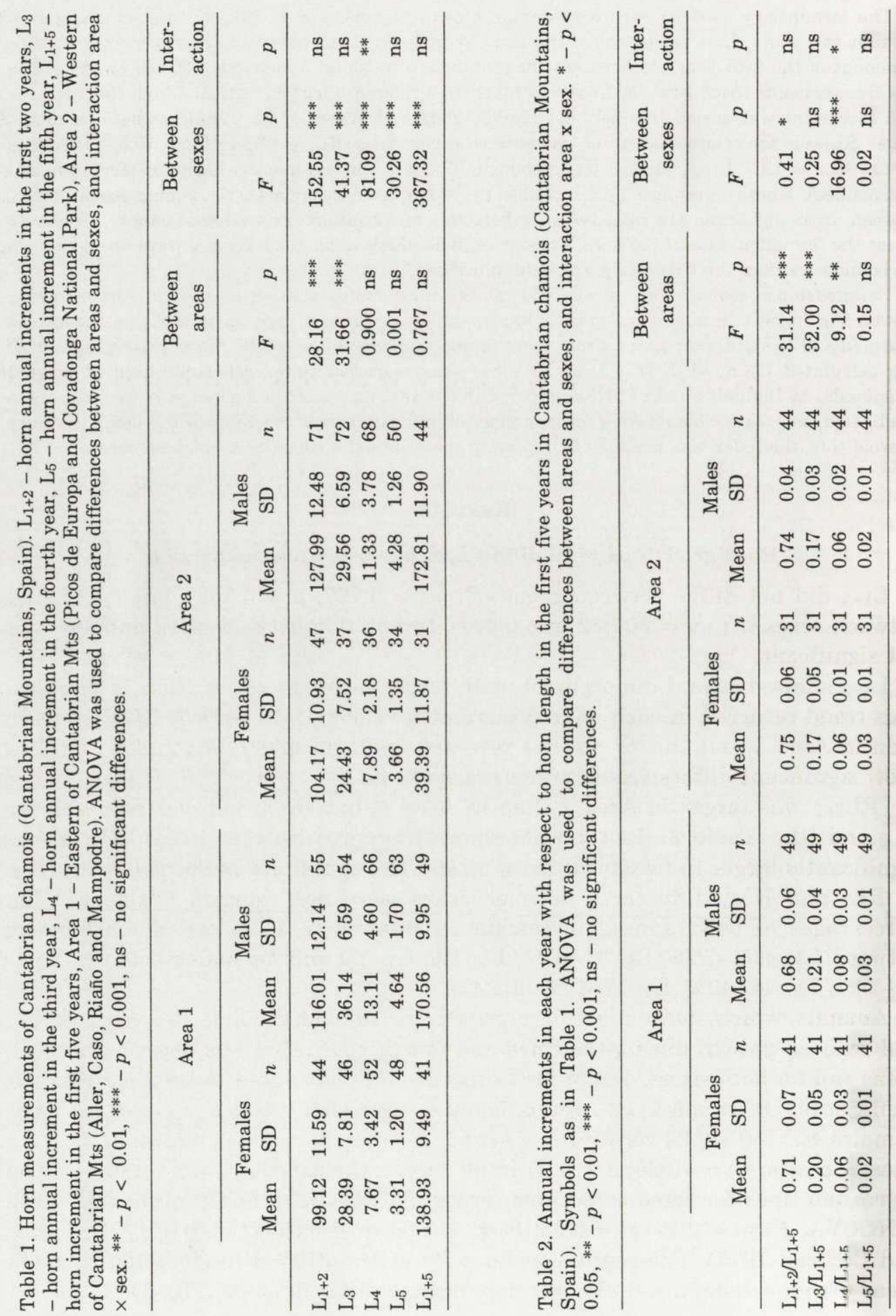




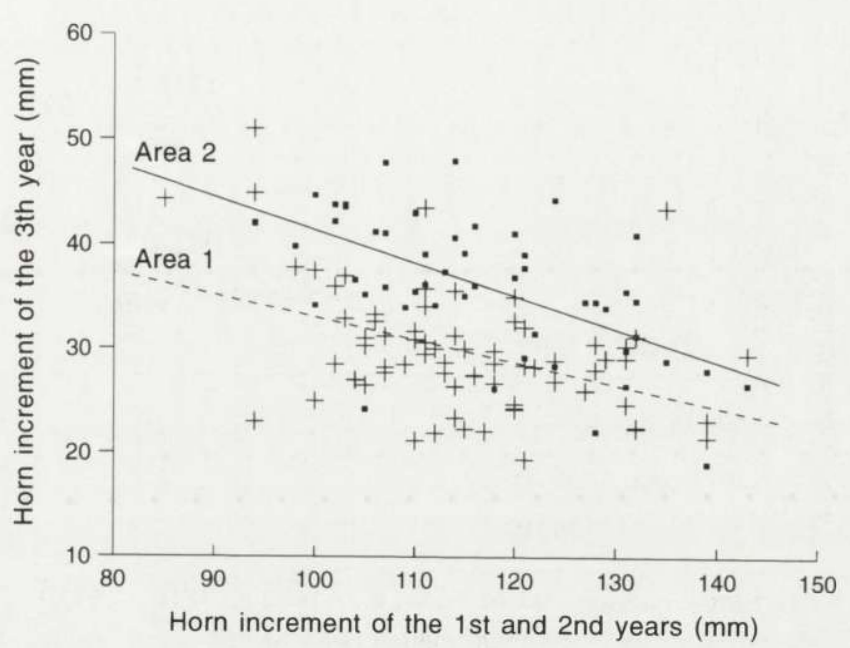

Fig. 1. Horn increment in the 3th year versus horn increment in the 1st and 2nd years pooled (mm), in males. Area 1 (dashed line and crosses): Eastern Cantabrian Mts; Area 2 (solid line and dots): Western Cantabrian Mts.

\section{Formation date of horn boundaries and winter horn growth}

In March, $54.8 \%$ of the sample $(n=31)$ was found to have indications of post-winter growth, and this proportion remained in April $(50.0 \%, n=20)$. In May, all horns observed had formed the last boundary $(n=9)$.

In two-year-old animals, shot between March and April, winter growth could be detected. At this age, epidermal tissue deposited throughout the winter months appears more bulkiness than epidermal tissue deposited in other months. This mark was not visible in two-year-old animals shot in June. The horn growth in the second winter of the animal's life represented $14 \%$ (mean $=17.36, \mathrm{SD}=2.80$, $n=15$ ) of the total increment in the first two years, both sexes pooled.

\section{Relationships between horn size and annual rainfall}

GI of $\mathrm{L}_{3}$ and $\mathrm{L}_{4}$ showed the same trend for the set of years considered $\left(r_{\mathrm{S}}=0.825, p<0.05\right.$, Spearman rank correlation coefficient). GI of $\mathrm{L}_{3}$ in the current year were positively correlated with annual precipitation, in $\mathrm{mm}$, in the previous year $\left(\mathrm{IG}_{\mathrm{n}}=0.0004 \times\right.$ rainfall $_{\mathrm{n}-1}-5.51, r^{2}=0.63, n=9, p<0.05, \mathrm{IG}_{\mathrm{n}}$ : horn growth index in the current year, rainfall $n-1$ : annual precipitation (in $\mathrm{mm}$ ) in the previous year, Fig. 2), but not with precipitation in the current year.

\section{Relationships between jaw length and horn size}

There was a significant correlation between jaw length and total horn length in both males and females (Females: $r_{\mathrm{P}}{ }^{2}=0.75$, Males: $r_{\mathrm{P}}{ }^{2}=0.54, p<0.05$ in all cases). Female correlations were higher than male $(p<0.001$, Correlation coefficients comparison, Zar 1984). 


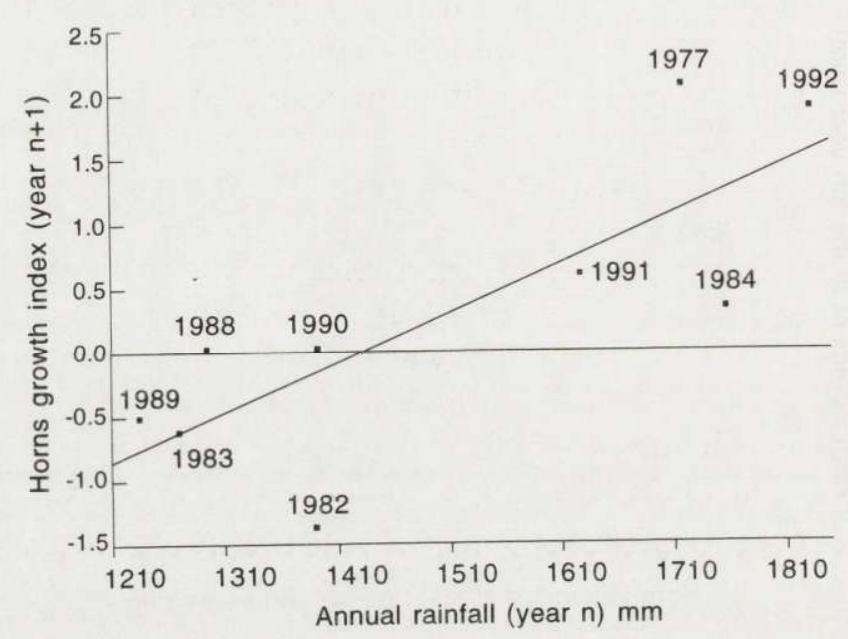

Fig. 2. Relationships between annual rainfall $(\mathrm{mm})$ in year $n$ and horn growth index in year $\mathrm{n}+1$. The year is shown next to each point.

\section{Discussion}

Horns obtained from hunted animals for analysis may not be truly representative of the whole population, as individuals to be killed are selected by the hunters (Hrabě and Koubek 1983, Hrabě et al. 1986). However, this source of information is useful when comparisons between horn growth patterns are made with respect to age and horn size.

THL and jaw-length were related in both sexes, which suggests that horn growth patterns can be used to estimate body-size growth patterns when only horn measurements are available. This would increase the value of the results from the study of hunting trophies. Fandos et al. (1989) also found good correlations between body weight and horn length in Cantabrian chamois. In our sample, the correlation coefficients of THL against jaw length were higher in females than in males. However, Fandos et al. (1989) found $r^{2}$ values for females lower than for males in the correlation of live weight against THL, body length and chest girth. This was possibly due to the higher energetic cost of reproduction. Body weight is, however, directly sensitive to changes in energetic demand, while jaw-length and the size of other bones are less affected.

Sexual dimorphism in horn length was evident at all ages, with males having longer horns than females (Table 1). However, this difference did not persist in all segments in the analysis of length relative to $\mathrm{L}_{1+5}$ (Table 2). Females had a higher relative horn growth rate than males during the first two years of life. This difference was reversed by the fourth year. However, males from other subspecies (R. r. rupicapra - Koubek and Hrabě 1983a, R. r. tatrica - Koubek and Hrabě 1984, R. r. carpatica - Hrabě et al. 1986) have been shown to have higher annual 
relative horn growth than females up to 3-4 years of age, with this difference reversed in older ages. In our population these differences in sexual dimorphism in relation to age may be due to differences in maturing date between sexes. However, we need additional information to test this hypothesis.

Sexual dimorphism in horn length of adult Cantabrian chamois is the highest of all subspecies according to available data. The ratio THL males / THL females for $R$. r. rupicapra, $R . r$. tatrica, $R$. r. carpatica, $R$. r. asiatica, $R . r$. pyrenaica, varies between 1.07 and 1.20 (mean $=1.14$ ) versus 1.23 in $R$. pyrenaica parva in this study, and the same value (1.23) was obtained when it was calculated using data from Fernández-López and García-González (1986).

The animals which showed rapid growth in the first two years of life had a reduced growth rate in the third and fourth year. These results are consistent with Bunnell (1978) and Massei et al. (1994) for rams of Dall sheep Ovis dalli and Bulgarian chamois R. r. balcanica, respectively, and Koubek and Hrabě (1983) in R. $r$. rupicapra from the Jeseníky Mountains (Czechoslovakia) and the Usov collection (Alps) of horn samples. In the present data, the total length of the first five segments did not differ between the two areas. This indicates that by five years of age differential annual growth during the previous years is compensated. Since the first two-year increments were pooled, it is not possible to establish if horn growth rate is faster during the first or the second year of life or both. In other studies, horn growth during the first year in relation to $\mathrm{L}_{1+5}$ was between $28.2 \%$ and $30.50 \%$ in females, and $31.80-38.60 \%$ in males. During the second year the proportions varied between $32.70-33.70 \%$ and $35.50-40.4 \%$ in females and males respectively (Koubek and Hrabě 1983a, 1984, Hrabě et al. 1986). These values indicate that a similar proportion of total horn growth occurs during the first and second years, and the large accumulated percentage in the $\mathrm{L}_{1+2}$ cathegory may be due to the growth in the first or second year (or both). In the first year, the variation might be due to differences in birth date or genetic differences. Genetic differences between both areas have not been found (Pérez-Barbería 1994b). At one year of age, early birth date animals had bigger horns than late birth animals. In the present data, the horn length at two years of age differed between areas. If birth date were the cause of the horn growth differences, it would therefore be expected that modes of birth date would also differ between areas. However, differences in birth date, due to geographical or environmental factors, are not expected because both areas are adjacent. The slower growth rate in the third year in relation to the growth in the two first years was similar between areas in males and females, but the regression line intercept of males from Area 2 was higher than males from Area 1. If horn increments are proportional to body-size increments, then this suggests a different optimum size in young animals ( $<3$ years) in both areas. However, since these differences did not persist at five years of age, this would indicate that small body-size is only advantageous in young animals from Area 1 . Information is not available on competition either within young age classes or between young animals and adults or livestock in both 
areas, which might help to explain this result. Another possibility may be that energetic investment in horn growth is of less importance than energetic investment of other body structures, and resource limitation in Area 1 influences horn growth in young age classes. Area 1 had a higher chamois density (19.9 animals $/ \mathrm{km}^{2}$ ) than Area 2 (6.5 animals $/ \mathrm{km}^{2}$ ) (J. M. Fernández-López, pers. comm.), this suggests the possibility of higher intra-specific competition in Area 1.

$\mathrm{L}_{3}$ and $\mathrm{L}_{4}$ growth indices for the years covered by the data were similar, suggesting that climatic conditions affect horn growth. There was a positive correlation between horn growth and precipitation in the previous year, although none was evident in relation to the present year's precipitation. Fandos (1991) found the same relationships in Capra pyrenaica. This seems to indicate the existence of a lag between this climatic parameter and horn growth (as Fandos pointed out). It is possible that the rainfall in the previous year determines the body condition at which the animals go into winter. Animals reaching spring in relatively good condition, may have an enhanced horn growth rate. However, if horn growth rate is affected in this way, it could reasonably be expected that winter weather conditions are also a contributory factor.

In March, half the sample showed post-winter horn growth. This indicates that when horn growth segments are used for aging, it is necessary to make the following correction: in the horns that show signs of recent post-winter growth, this portion should not be counted until the putative birth date (1st May, Pérez-Barbería 1994a).

Schröder (1971) and Koubek and Hrabě (1983a) pointed out that horns continue growth throughout the winter, and growth does not stop as Couturier (1938) commented. In this study, the horns of young animals (2 years old), where growth rate is high, grew during winter. During the second winter of the animals life, growth of $14 \%$ in relation to horn length during the first two years was recorded.

Acknowledgements: We are indebted to G. Mutuberría, J. Ruiz and A. Nuño for their help in the laboratory work. Also to Biogestión and game keepers of Principado de Asturias for obtaining the horn samples. O. Hernández assisted in several aspects of this study. A. Melacini and J. Laker reviewed the English version. The research was supported by CICYT (Project 91-0911-FOR-217) and Consejería de Medio Ambiente y Urbanismo del Principado de Asturias (Grant 04-060-91). For the duration of this study the senior author held a grant from FICYT. The reviews of this paper were carried out by the senior author at The Macaulay Land Use Research Institute, supported by funding from Programa de Becas Formación de Personal Investigador en el Extranjero (Ministerio de Educación y Ciencia, Spain).

\section{References}

Bargagli R. and Lovari S. 1984. Age correlation between horn segments and tooth cementum annuli in the chamois (Rupicapra pyrenaica ornata) (Artiodactyla, Bovidae). Säugetierkundliche Mitteilungen 31: 179-183.

Bunnell F. L. 1978. Horn growth and population quality in Dall sheep. Journal of Wildlife Management 42: 764-775.

Couturier M. A. J. 1938. Le Chamois. Arthaud, Grenoble: 1-549. 
Fandos P. 1991. La cabra montés (Capra pyrenaica) en el Parque Natural de las Sierras de Cazorla, Segura and Las Villas. ICONA, Madrid: 1-176.

Fandos P., Vigal C. R. and Fernández-López J. M. 1989. Weight estimation of Spanish ibex, Capra pyrenaica, and Chamois, Rupicapra rupicapra (Mammalia, Bovidae). Zeitschrift für Säugetierkunde 54: 239-242.

Fernández-López J. M. and García-González R. 1986. Craniométric comparée entre les chamois pyrénéen et cantabrique. Mammalia 50: 87-97.

Hrabě V. and Koubek P. 1983. Horns of the chamois, Rupicapra rupicapra rupicapra, from the Jeseníky Mountains (Czechoslovakia). Folia Zoologica 32: 23-31.

Hrabě V. and Koubek P. 1984. Craniometrical characteristics of Rupicapra rupicapra tatrica (Mamm., Bovidae). Folia Zoologica 33: 73-84.

Hrabě V., Weber P. and Koubek P. 1986. The morphometrical characteristics and the dynamics of horn growth in Rupicapra rupicapra carpatica (Mamm., Bovidae). Folia Zoologica 35: 43-54.

Koubek P. and Hrabě V. 1983a. Dynamic of horn growth in the Jeseníky Mts. population of chamois, Rupicapra rupicapra rupicapra (CSSR). Folia Zoologica 32: 97-107.

Koubek P. and Hrabě V. 1983b. Craniometrical characteristics of Rupicapra rupicapra caucasica. Folia Zoologica 32: 213-223.

Koubek P. and Hrabě V. 1984. Morphometrical characteristics and horn growth dynamics in Rupicapra rupicapra tatrica (Mammalia, Bovidae). Folia Zoologica 33: 289-302.

Koubek P., Weber P. and Hrabě V. 1985. Craniometrical characteristics of Rupicapra rupicapra carpatica (Mamm., Bovidae). Folia Zoologica 34: 227-284.

Lovari S. and Scala C. 1984. Revision of Rupicapra genus. IV. Horn biometrics of Rupicapra rupicapra asiatica and its relevance to the taxonomic position of Rupicapra rupicapra caucasica. Zeitschrift für Säugetierkunde 49: 246-253.

Massei G., Randi E. and Genov P. 1994. The dynamics of the horn growth in Bulgarian chamois Rupicapra rupicapra balcanica. Acta Theriologica 39: 195-199.

Masini F. and Lovari S. 1988. Systematics, phylogenetic relationships and dispersal of the chamois Rupicapra spp. Quaternary Research 30: 339-349.

Miller C. and Hartl G. B. 1986. Genetic variation in two alpine populations of chamois, Rupicapra rupicapra L. Zeitschrift für Säugetierkunde 51: 114-121.

Mitchell B. and Crisp J. M. 1981. Some properties of red deer (Cervus elaphus) at exceptionally high population-density in Scotland. Journal of Zoology, London 193: 157-169.

Nascetti G., Lovari S., Lanfranchi P., Berducou C., Mattiucci S., Rossi L. and Bullini L. 1985. Revision of Rupicapra genus. III. Electrophoretic studies demostrating species distinction of chamois populations of the Alps from those of the Apennines and Pyrenees. [In: Biology and management of mountain ungulates. S. Lovari, ed]. Croom-Helm, London: 56-62.

Niethammer G. 1957. Alte Gamsgei $\beta$ mit breiten "Jahresring”. Zeitschrift für Jagdwissenschaft 3: 87-88.

Pérez-Barbería F. J. 1994a. Determination of age in Cantabric chamois (Rupicapra pyrenaica parva) from jaw tooth-row eruption and wear. Journal of Zoology, London 233: 649-656.

Pérez-Barbería F. J. 1994b. Biología, ecología y caracterización genética del Rebeco Cantábrico (Rupicapra pyrenaica parva). Ph D thesis, Oviedo University, Spain: 1-112.

Pérez-Barbería F. J. and Fernández-López J. M. 1996. Using cementum annuli to estimate Cantabrian chamois age. Journal of Wildlife Management 60: 62-67.

Pflieger R. 1982. Le Chamois: son dentification et sa vie. Gerfaut Club-Princesse, Orleans: 1-177.

Reimers E. 1983. Reproduction in wild reindeer in Norway. Canadian Journal of Zoology 61: 211-217.

Scala C. and Lovari S. 1984. Revision of Rupicapra genus. II. A skull and horn statistical comparison of Rupicapra rupicapra ornata and R. rupicapra pyrenaica chamois. Bolletino Zoologico 51: 285-294.

Schröder W. 1971. Untersuchungen zur Ökologie des Gamswildes (Rupicapra rupicapra L.) in einem Vorkommen der Alpen. 1. Teil. Zeitschrift für Jagdwissenschaft 17: 113-168. 
Schröder W. 1985. Management of mountain ungulates. [In: Biology and management of mountain ungulates. S. Lovari, ed]. Croom-Helm, London: 179-196.

Schröder W. and Elsner-Schack I. V. 1985. Correct age determination in chamois. [In: Biology and management of mountain ungulates. S. Lovari, ed]. Croom-Helm, London: 65-70.

Skogland T. 1989. Natural selection of wild reindeer life history traits by food limitation and predation. Oikos 5: 101-110.

Snedecor G. W. and Cochran W. G. 1975. Métodos estadísticos. CECSA, México: 1-703.

Zar J. H. 1984. Biostatistical analysis. 2nd edition. Prentice-Hall, New Jersey: 1-718.

Received 5 May 1995, accepted 10 October 1995. 